\title{
Renin Measurement
}

National Cancer Institute

\section{Source}

National Cancer Institute. Renin Measurement. NCI Thesaurus. Code C74893.

The determination of the amount of renin present in a sample. 